\title{
Pertanggungjawaban Pidana Anggota Militer yang Melakukan Tindak Pidana Insubordinasi dengan Tindakan Nyata dalam Peradilan Militer
}

\author{
Criminal Responsibility of Military Members that do the Criminal Action of \\ Insubordination with Real Action in Military Justice
}

\author{
La Ode Abdul Tamin \\ TNI AD \\ E-mail: laodeabdultamin@gmail.com \\ Oheo K. Haris \\ Pascasarjana Universitas Halu Oleo \\ E-mail:oheokh@gmail.com \\ Sabrina Hidayat \\ Pascasarjana Universitas Halu Oleo \\ E-mail: sabrina.hidayat54@yahoo.com
}

\begin{abstract}
The purpose of this study was to find out and analyze responsibility of perpetrators of criminal acts of insubordination with concrete actions according to the Criminal Procedure Code and to prove the perpetrators of criminal acts insubordination with concrete action taken by members of the TNI in the military court environment.

This type of research is a normative research with a regulatory approach and a conceptual approach.This research is a form of Legal Responsibility of Military Members who commit criminal acts of insubordination with concrete actions as a norm in military legislation contained in the Military Criminal Code (KUHPM) and the Military Discipline Law can conflict with rules of military life or disciplinary violations due to ANKUM's considerations and policies so that they were not resolved through the Military Criminal Procedure Code (KUHAPMIL).

Based on the results of the study it can be concluded that the responsibility of the perpetrators of criminal acts with concrete actions against superiors carried out by soldiers or members of the lower rank TNI in accordance with article 106-108 of the Criminal Procedure Code must be accounted for by military criminal law stipulated in the provisions of the Military Criminal Law (KUHPM) pursuant to article 106 that the military intentionally attacks a superior, opposes it with violence or threats of violence, seizes his independence to act or forces him with violence or threat of violence to carry out or neglect an official job, is threatened because of
\end{abstract}


insubordination with actual imprisonment 9 years and verification of the perpetrators of criminal acts of insubordination with concrete actions through military courts that have been delegated by PAPERA through Military Prosecutors accompanied by indictments, the presiding judge must prove the defendant's fault whether it is proven or not as charged by the Military Prosecutor pursuant to article 171 KUHAPMIL that is, the judge may not impose a criminal sentence on a person except if with at least two valid evidences, he obtains the conviction that a criminal act actually accurred and that the defendant is guilty of doing it.

Keyword: Criminal liability; criminal acts of insubordination; military justice

Abstrak: Penelitian ini ialah untuk mengetahui dan menganalisis pertanggungjawaban pidana pelaku tindak pidana insubordinasi dengan tindakan nyata menurut KUHPM dan pembuktian pelaku tindak pidana insubordinasi dengan tindakan nyata yang dilakukan oleh anggota TNI di lingkungan peradilan Militer.

Tipe penelitian ini adalah tipe penelitian normatif dengan pendekatan peraturan perundang-undangan dan pendekatan konsep. Penelitian ini merupakan bentuk Tanggung jawab Hukum Anggota Militer yang melakukan tindak pidana Insubordinasi dengan tindakan nyata sebagai sebuah sistim norma dalam perundang-undangan militer yang termuat dalam Kitab Undang-Undang Hukum Pidana Militer (KUHPM) dan Kitab Undang-Undang Hukum Disiplin Militer dapat dikatakan bertentangan dengan aturan dalam kehidupan militer atau pelanggaran disiplin dikarenakan atas pertimbangan dan kebijakan ANKUM sehingga tidak diselesaikan melalui Hukum Acara Pidana Militer (KUHAPMIL).

Berdasarkan hasil penelitian dapat disimpulkan bahwa Pertanggungjawaban pelaku tindak pidana Insubordinasi dengan tindakan nyata terhadap atasan yang dilakukan oleh prajurit atau anggota TNI yang berpangkat lebih rendah sesuai Pasal 106-108 KUHPM harus dipertanggungjawabkan secara hukum pidana Militer yang diatur dalam ketentuan Kitab Undang-Undang Hukum Pidana Militer (KUHPM) sesuai Pasal 106 bahwa Militer yang sengaja menyerang seorang atasan, melawannya dengan kekerasan atau ancaman kekerasan, merampas kemerdekaannya untuk bertindak ataupun memaksanya dengan kekerasan atau ancaman kekerasan untuk melaksanakan atau mengabaikan suatu pekerjaan dinas, diancam karena insubordinasi dengan tindakan nyata dengan pidana penjara maksimum sembilan tahun dan Pembuktian pelaku tindak pidana Insubordinasi dengan tindakan nyata melalui pengadilan Militer yang telah dilimpahkan oleh PAPERA melalui Oditur Militer disertai surat Dakwaan, Hakim ketua sidang harus membuktikan kesalahan terdakwa apakah terbukti atau tidak sebagaimana didakwakan oleh Oditur Militer sesuai Pasal 171 KUHAPMIL yaitu Hakim tidak boleh menjatuhkan pidana kepada seseorang kecuali apabila dengan sekurang-kurangnya dua alat bukti yang sah, ia memperoleh keyakinan bahwa suatu tindak pidana benar-benar terjadi dan bahwa terdakwalah yang bersalah melakukannya.

Kata kunci: Pertanggungjawaban Pidana; Tindak Pidana Insubordinasi; Peradilan Militer

\section{PENDAHULUAN}

Pertanggungjawaban pidana merupakan salah satu tanggung jawab hukum pelaku kejahatan di Indonesia, Untuk adanya pertanggungjawaban pidana harus terlebih dahulu siapa yang dipertanggungjawabkan. Pertanggungjawaban tanpa adanya kesalahan dari 
pihak yang melanggar dinamakan leer van het materiele feit (fait materielle) ${ }^{1}$. Kemampuan bertanggung jawab dapat diterapkan hanya kepada seorang yang mampu bertanggungjawab dan dapat mempertanggungjawabkan perbuatannya sebagaimana dalam asas pidana menyatakan bahwa tiada pidana jika tidak ada kesalahan yang merupakan asas pertanggungjawaban. ${ }^{2}$ Hukum Pidana memuat peraturan-peraturan yang mengandung keharusan dan larangan terhadap pelanggarnya yang diancam dengan hukuman berupa siksa badan, pengertian tersebut jelas menyebutkan hukum pidana berisikan peraturan tentang keharusan sekaligus larangan. ${ }^{3}$ Hukum Pidana yang bersifat umum adalah hukum pidana yang mengatur tentang tindak pidana yang dilakukan oleh masyarakat umum, sedangkan Hukum Pidana yang bersifat Khusus adalah hukum pidana yang mengatur tentang tindak pidana yang dilakukan oleh masyarakat tertentu. Salah satu Hukum Pidana yang bersifat Khusus adalah Hukum Pidana Militer, yaitu hukum yang mengatur tentang tindak pidana yang dilakukan oleh Militer. Sebagaimana hukum pidana umum yang memiliki Kitab Undang-Undang Hukum Pidana (KUHP), maka dalam hukum pidana militer memiliki Kitab Undang-Undang Hukum Pidana Militer (KUHPM).

Hukum pidana militer dalam arti luas mencakup pengertian hukum pidana militer dalam arti materiil dan hukum pidana militer dalam arti formal, Hukum pidana materiil merupakan kumpulan peraturan tindak pidana yang berisi perintah dan larangan untuk menegakkan ketertiban hukum dan apabila perintah dan larangan itu tidak ditaati maka diancam hukuman pidana, sedangkan hukum pidana formal yang lebih dikenal disebut hukum acara pidana merupakan kumpulan peraturan hukum yang memuat ketentuan tentang kekuasaan peradilan dan cara pemeriksaan, pengusutan, penuntutan dan penjatuhan hukuman bagi militer yang melanggar hukum pidana material, Hukum pidana formal disebut juga hukum acara pidana yang bertugas mempertahankan hukum pidana material. ${ }^{4}$ Salah satu tindak pidana yang diatur dalam Kitab Undang-Undang Hukum Pidana Militer (KUHPM), adalah Tindak pidana insubordinasi Pasal 106 Kitab UndangUndang Hukum Pidana Militer (KUHPM).

Tindakan Insubordinasi merupakan tindakan yang melawan atasan dalam kehidupan militer, Olehnya karena itu disiplin prajurit wajib dan mutlak harus ditegakkan

\footnotetext{
Moeljanto, Asas-Asas Hukum Pidana, Jakarta: Rineka Cipta, 2009, hlm. 165.

Ibid., hlm. 2.

Ismu Gunadi dan Jonaedi Efendi, Cepat dan Mudah Memahami Hukum Pidana, Jakarta: PT Prestasi Pustakaraya, 2011, hlm. 2.

4 Moch. Faisal Salam, Hukum Pidana Militer di Indonesia, Bandung: 2002, hlm. 4.
} 
demi tumbuh dan berkembangnya Tentara Nasional Indonesia (TNI) dalam mengemban dan mengamalkan tugas yang telah dipercayakan oleh bangsa dan Negara kepadanya. Oleh karena itu, sudah menjadi kewajiban setiap prajurit untuk menegakkan disiplin.

Pelanggaran yang dilakukan oleh prajurit yang paling menonjol saat ini yaitu kasus insubordinasi dengan tindakan nyata, Tindakan/perbuatan prajurit yang melakukan tindak pidana insubordinasi dengan tindakan nyata tersebut akan merusak wibawa, martabat dan nama baik Tentara Nasional Indonesia (TNI) baik yang berada di satuan tempur maupun yang ada di Komando kewilayahan baik perorangan maupun satuan, hal ini disebabkan karena kurangnya pengawasan dan pengendalian unsur pimpinan baik unsur pimpinan bawahan maupun unsur pimpinan satuan serta kurangnya kesadaran dan pemahaman anggota dalam menyikapi Sapta Marga, Sumpah Prajurit dan 8 (Delapan) Wajib TNI dalam setiap pelaksanaan tugas di mana pun berada serta kurangnya kesadaran prajurit dalam menyikapi perintah pimpinan/atasan yang memberi perintah sehingga memilih jalan untuk melawan atasan/pimpinan. Militer yang menyerang atasan dengan tindakan nyata karena dengan sengaja menyerang atasan yang dilakukan dengan perbuatan tertentu yang dapat dilakukan secara langsung merupakan tindakan insubordinasi yang harus diselesaikan secara hukum dalam hukum pidana militer. ${ }^{5}$ Olehnya itu dalam kasus tindak pidana insubordinasi yang dilakukan oleh prajurit seharusnya diproses sesuai dengan peraturan perundang-undangan hukum pidana militer bukan diselesaikan secara hukum disiplin militer hanya karena atas pertimbangan dan kebijakan seorang ANKUM. Apabila perbuatan melawan atasan/pimpinan dengan tindakan nyata tersebut tidak diproses melalui peradilan Militer akan menimbulkan masalah yang lebih besar dan akan berdampak kepada prajurit yang lain berupa :

1. Tidak menghormati atasan;

2. Mengulangi perbuatan yang sama;

3. Ketidaktaatan perintah terhadap atasan.

Maka berdasarkan uraian di atas, penulis tertarik untuk mengkaji tindak pidana insubordinasi yang dilakukan prajurit terhadap atasan dengan mengambil judul “Pertanggungjawaban Pidana Anggota Militer Yang Melakukan Tindak Pidana Insubordinasi Dengan Tindakan Nyata Dalam Peradilan Militer."

5 Ibid., hlm. 8. 


\section{METODE PENELITIAN}

Tipe yang digunakan dalam penelitian ini adalah tipe penelitian hukum normatif. Penelitian hukum normatif yaitu penelitian hukum yang meletakkan hukum sebagai sebuah bangunan sistem Norma. Tipe penelitian normatif ini dilakukan dengan Cara mengkaji berbagai Konsep hukum yakni konsep Pertanggungjawaban pidana, Kepemimpinan satuan, Konsep Pembuktian dan Pemidanaan Militer serta berbagai peraturan yang berkaitan dengan tindak pidana militer. Penelitian ini menekankan Pada analisis Konsep pertanggungjawaban pidana dan pembuktian anggota militer yang melakukan tindak pidana insubordinasi dengan tindakan nyata.

\section{ANALISIS DAN PEMBAHASAN}

\section{Pertanggungjawaban Pidana Pelaku Tindak Pidana Insubordinasi Dengan Tindakan} Nyata menurut KUHPM

Tindak pidana Insubordinasi diatur di dalam Pasal 106 KUHPM yang menyatakan sebagai berikut: dihukum sebagai bersalah karena Insubordinasi, anggota tentara yang dengan sengaja tindakan nyata menyerang seseorang atasan, melawannya dengan kekerasan atau ancaman kekerasan, merampas kemerdekaannya untuk bertindak, ataupun memaksanya dengan kekerasan atau ancaman kekerasan untuk melaksanakan atau mengabaikan suatu pekerjaan dinas, diancam karena Insubordinasi dengan tindakan nyata. Insubordinasi merupakan tindak pidana melawan atasan yang dilakukan oleh prajurit TNI di saat jam dinas, maupun di luar jam dinas dengan syarat atasan tersebut mendapatkan surat perintah dinas untuk mengemban tugas atau mewakili kompi kesatuannya.

Tindak pidana insubordinasi ini diatur berkaitan dengan perbuatan seorang bawahan dalam hal ini seorang tentara yang memiliki pangkat lebih rendah terhadap atasan yang pangkatnya lebih tinggi darinya, Perbuatan yang dapat dihukum dalam pasal insubordinasi dengan perbuatan yang terdiri dari: ${ }^{6}$

\section{Menyerang dengan tindakan}

Dengan sengaja menyerang tubuh seorang atasan, yang dilakukan dengan perbuatan tertentu. Perbuatan itu dapat dilakukan secara langsung misalnya menendang, memukul, menumbuk atau dapat pula dilakukan secara tidak langsung misalnya menembak, melempar, atau menggunakan berbagai alat lainnya. Penyerangan itu harus sedemikian

\footnotetext{
$6 \quad$ Ibid., hlm. 266.
} 
rupa sehingga tubuh atau pakaian atasan tersebut tersentuh walau atasan itu tidak merasa sakit, Memegang kemeja/baju atasan sehingga kancing bajunya terlepas, dianggap juga sebagai penyerangan dengan tindak atau perbuatan. Akan tetapi melakukan pemukulan atau menendang yang tidak mengenai tubuh atasan yang dituju tidak dapat dikatakan melakukan penyerangan dengan tindakan atau perbuatan. ${ }^{7}$

\section{Melawan dengan kekerasan atau ancaman kekerasan}

Istilah kekerasan di dalam pasal ini harus diartikan lebih luas daripada istilah yang sama dalam pasal 212 KUHP. Seorang anggota militer yang melakukan perlawanan sewaktu akan ditangkap oleh yang berwajib dengan jalan menyentakkan tangannya atau berpegang pada suatu benda, termasuk melawan dengan kekerasan. Jika dibandingkan dengan pasal 106 di atas, terdapat persamaan dalam hal mengancam dengan kekerasan. Bedanya ialah bahwa ancaman dalam pasal 106 ini khusus ditujukan untuk mengadakan perlawanan kepada atasan, sebagai reaksi atas tindakan seorang atasan.

\section{Merampas kemerdekaan untuk berbuat}

Merampas kemerdekaan untuk berbuat dari seorang atasan, dengan sengaja menghalanghalangi kemerdekaan atasan untuk atau mengambil tindakan-tindakan dianggap perlu atau memberikan perintah-perintah dan sebagainya. Memberikan obat tidur, mengurung di dalam sebuah kamar, mengikat kaki dan tangan, merupakan perbuatan perampasan kemerdekaan seorang atasan.

\section{Memaksa dengan kekerasan atau ancaman kekerasan untuk melakukan atau mengabaikan suatu pekerjaan dinas}

Pertanggungjawaban pelaku tindak pidana Insubordinasi dengan tindakan nyata terhadap atasan yang dilakukan oleh prajurit atau anggota TNI yang berpangkat lebih rendah sesuai Pasal 106-109 KUHPM harus dipertanggungjawabkan secara hukum pidana Militer yang diatur dalam ketentuan Kitab Undang-Undang Hukum Pidana Militer (KUHPM) sebagai berikut:

1. Pasal 106

Militer yang sengaja menyerang seorang atasan, melawannya dengan kekerasan atau ancaman kekerasan, merampas kemerdekaannya untuk bertindak ataupun memaksanya dengan kekerasan atau ancaman kekerasan untuk melaksanakan

$7 \quad$ Ibid., hlm. 267 
atau mengabaikan suatu pekerjaan dinas, diancam karena insubordinasi dengan tindakan nyata dengan pidana penjara maksimum sembilan tahun.

2. Pasal 107

Insubordinasi dengan tindakan nyata, yang direncanakan terlebih dahulu, diancam dengan pidana penjara maksimum sepuluh tahun

3. Pasal 108

Insubordinasi dengan tindakan nyata yang dilakukan oleh dua orang atau lebih secara bersatu, diancam karena perlawanan nyata bersama dengan pidana penjara maksimum dua belas tahun.

4. Pasal 109

Insubordinasi dengan tindakan nyata dalam waktu perang diancam dengan pidana mati, pidana penjara seumur hidup atau sementara maksimum dua puluh tahun.

Sebagai sarana dalam rangka penegakan hukum dan keadilan dalam mewujudkan kehidupan yang tertib dan tenteram dalam masyarakat, ketentuan dalam hukum acara pidana harus dilaksanakan sesuai dengan tujuan dan aturannya. Insubordinasi dapat diproses karena adanya pengaduan langsung dari korban yaitu atasan dan atau laporan seorang atasan yang berhak menghukum (Ankum). Bentuk penyelesaian bagi anggota militer yang melakukan tindak pidana Insubordinasi, yaitu pertanggungjawaban pidana melalui proses pengadilan. ${ }^{8}$ Penerapan penyelesaian pertanggungjawaban tindakan Insubordinasi sesuai ketentuan Undang-Undang Nomor 31 Tahun 1997 melalui proses peradilan.

\section{Teori Pertanggungjawaban Pidana}

Menurut Ruslan Saleh, pertanggugjawaban pidana adalah sesuatu yang dipertanggungjawabkan secara pidana terhadap seseorang yang melakukan perbuatan pidana atau tindak pidana. ${ }^{9}$ Pelaku tindak pidana dapat dipidana apabila memenuhi syarat bahwa tindak pidana yang dilakukannya memenuhi usur-unsur yang telah ditentukan dalam Undang-Undang. Dilihat dari sudut terjadinya tindakan yang dilarang, seseorang akan dipertanggungjawabkan atas tindakan-tindakan tersebut, apabila tindakan tersebut melawan hukum serta tidak ada alasan pembenar atau peniadaan sifat melawan hukum untuk pidana yang dilakukannya. Dan dilihat dari sudut kemampuan bertanggungjawab maka hanya seseorang yang mampu bertanggungjawab yang dapat dipertanggungjawabkan atas perbuatannya. Dalam hal dipidananya seseorang yang melakukan perbuatan seperti melawan hukum tergatung dari apakah dalam melakukan

$8 \quad$ Ibid., hlm. 25.

9 Ruslan Saleh, Perbuatan Pidana dan Pertanggungjawaban Pidana, Jakarta: Aksara Baru, 1990, hlm. 80. 
perbuatan ia mempunyai kesalahan dan apabila orang yang melakukan perbuatan itu memang melawan hukum, maka ia akan dipidana. Berdasarkan hal tersebut, Andi Hamzah menjelaskan bahwa pembuat (dader) harus ada unsur kesalahan dan bersalah yang harus memenuhi unsur yaitu: ${ }^{10}$

1. Kemampuan bertanggungjawab atau dapatnya dipertanggung jawabkan dari si pembuat.

2. Adanya kaitan psikis antara pembuat dan perbuatan, yaitu adanya sengaja atau kesalahan dalam arti sempit (culpa). Pelaku mempunyai kesadaran yang mana pelaku seharusnya dapat mengetahui akan adanya akibat yang ditimbulkan dari perbuatannya.

3. Tidak adanya dasar peniadaan pidana yang menghapus dapatnya dipertanggungjawabkan sesuatu perbuatan kepada pembuat.

Asas legalitas hukum pidana Indonesia yang diatur dalam Pasal 1 ayat (1) KUHP menyatakan bahwa seseorang baru dapat dikatakan melakukan perbuatan pidana apabila perbuatannya tersebut telah sesuai dengan rumusan dalam Undang-Undang hukum pidana. Meskipun orang tersebut belum tentu dapat dijatuhi hukum pidana, harus memenuhi unsur-unsur perbuatan pidana dan pertanggungjawaban pidana.

\section{Teori Kepemimpinan}

Ada tiga teori kepemimpinan menurut para ahli yang mesti diketahui. Kepemimpinan memang tidak cukup hanya dilihat dari satu sudut pandang saja, melainkan mencakup semua kegiatan mulai dari penyiapan secara berencana hingga dapat melatih calon pimpinan yang baru untuk masa yang akan datang guna kaderisasi yang lebih baik yaitu :

1) Teori Sifat.

Teori sifat berdasar atas dasar pemikiran bahwa keberhasilan pemimpin bergantung dengan sifatnya, ciri khas yang dimiliki, dan perangainya. Maka untuk menjadi pemimpin yang sukses dibutuhkan kemampuan pribadi seorang pemimpin. Kemampuan pribadi yang dimaksud tidak lain berupa kualitas dengan berbagai sifar, ciri, dan perangainya.

2) Teori Perilaku

10 Andi Hamzah, Asas-Asas Hukum Pidana, Jakarta: Rieka Cipta, 1997, hlm. 130. 
Teori perilaku berdasar atas kepemimpinan yang merupakan perilaku individu saat menjalankan kegiatan mengarahkan atau membimbing kelompok tertentu guna mencapai tujuan. Dalam hal ini seorang pemimpin memiliki beberapa deskripsi perilaku. Mulai dari seorang pemimpin yang cenderung mengutamakan bawahan, bersikap ramah, mendukung, membela, mau mendengarkan, mau berkonsultasi, dan memikirkan kesejahteraan kelompoknya, Namun, ada pula seorang pemimpin yang berorientasi pada bawahan atau produksi. Pemimpin yang berorietasi pada bawahan ditandai dengan adanya penekanan atas hubungan atasan dan bawahan, sementara pimpinan yang berorientasi pada produksi cenderung ditandai dengan penekanan pada segi teknis pekerjaan.

3) Teori Situasional

Teori situasional, sukses tidaknya kepemimpinan seorang pemimpin ditentukan oleh ciri kepemimpinannya itu sendiri. Misalnya dengan berperilaku yang sesuai dengan tuntutan situasi organisasional dan situasi kepemimpinan yang dihadapi tentu dengan mempertimbangkan faktor ruang dan waktu.

\section{Pembuktian Tindak Pidana Insubordinasi Dengan Tindakan Nyata Dalam Peradilan Militer}

Pembuktian tindak pidana Insubordinasi dalam peradilan Militer sama halnya dengan pembuktian pada tindak pidana umum, hanya saja pelakunya anggota Militer. Pembuktian merupakan salah satu bagian terpenting dalam proses pemeriksaan suatu perkara pidana. Pembuktian sebagai titik sentral dalam proses pemeriksaan suatu perkara pidana, serta memiliki arti penting atau hanya diperlukan jika terjadi persengketaan atau perkara di pengadilan. Menurut Max M. Houck, evidence atau bukti dapat didefinisikan sebagai pemberian informasi dalam penyidikan yang sah mengenai fakta yang kurang lebih seperti apa adanya. ${ }^{11}$ Dalam Kamus Bahasa Indonesia, kata "bukti" terjemahan dari bahasa Belanda, bewijs. ${ }^{12}$ Diartikan sebagai sesuatu yang menyatakan kebenaran suatu peristiwa. Dalam Kamus Hukum, bewijs diartikan sebagai segala sesuatu yang memperlihatkan kebenaran fakta tertentu atau ketidakbenaran fakta lain oleh para pihak

11 Max M. Houck, Essentials Of Forensic Science: Trace Evidence, New York: An Imprint Of Infobase Publisbing, 2009), hlm. 1.

12 P.J.H.O. Schut En R.W Zandvoort, Engels Woordenboek-Eerste Deel-Engels-Nederlands Groningen-Batavia: J.B. Wolters Uitgeversmaatschappij, 1948, hlm. 242. 
dalam perkara pengadilan, guna memberi bahan kepada hakim bagi penilaiannya. ${ }^{13}$ Pembuktian adalah perbuatan membuktikan, membuktikan berati memberi atau memperlihatkan bukti, melakukan sesuatu sebagai kebenaran, melaksanakan, menandakan, menyaksikan dan meyakinkan. ${ }^{14}$ R. Subekti berpendapat bahwa membuktikan ialah meyakinkan hakim tentang kebenaran dalil atau dalil-dalil yang dikemukakan dalam suatu persengketaan. ${ }^{15}$ Dari beberapa definisi perihal bukti, membuktikan, dan pembuktian dapatlah ditarik kesimpulan bahwa bukti merujuk pada alat-alat bukti termasuk barang bukti yang menyatakan kebenaran suatu peristiwa.

Larry E. Sullivan dan Marie Simonetti membagi bukti dalam tiga kategori, yaitu bukti langsung, bukti tidak langsung dan bukti fisik. Pertama, Bukti langsung membentuk unsur kejahatan melalaui penuturan saksi mata, pengakuan atau apa pun yang diamati termasuk tulisan dan suara, video atau rekaman digital lainnya, kedua, bukti tidak langsung didasarkan pada perkataan dan analisis yang masuk akal. Sistim pembuktian sesuai Pasal 171 KUHAPMIL yaitu Hakim tidak boleh menjatuhkan pidana kepada seseorang kecuali apabila dengan sekurang-kurangnya dua alat bukti yang sah, ia memperoleh keyakinan bahwa suatu tindak pidana benar-benar terjadi dan bahwa terdakwalah yang bersalah melakukannya.

Menyimak bunyi Pasal tersebut di atas, HAPMIL menunjukkan bahwa yang dianut dalam sistim pembuktian ialah sistim negatif menurut Undang-Undang. Penyebutan dua alat bukti, maka berarti bahwa hakim pidana tidak boleh menjatuhkan pidana kepada seorang hanya didasarkan atas satu alat bukti saja. ${ }^{16}$ Kecuali dalam perkara yang diajukan dalam acara pemeriksaan cepat yakni pada tindak pidana ringan dan perkara pelanggaran lalu lintas jalan, maka keyakinan hakim cukup didukung oleh satu alat bukti saja. Apabila ternyata terdakwa terbukti bersalah melakukan tindak pidana yang didakwakan kepadanya, dimana telah dipenuhi sekurang-kurangnya dua alat bukti dan hakim yakin bahwa tindak pidana telah terjadi dan terdakwa bersalah melakukannya sebagaimana dimaksud dalam Pasal 190 ayat 1 HAPMIL. Dalam menjatuhkan putusan berupa penghukuman/pemidanaan maka hakim harus memperhatikan apakah terdakwa ditahan

\footnotetext{
13 Andi Hamzah, Kamus Hukum, Jakarta: Ghalia Indonesia, 1986, hlm. 83.

14 Soedirjo, Jaksa dan Hakim dalam Proses Pidana, Jakarta: Akademika Pressindo, 1985, hlm. 47. Bandingkan dengan Lilik Mulyadi, Pembalikan Beban Pembuktian Tindak Pidana Korupsi, Bandung: Alumni, 2007, hlm. 84.

15 R. Subekti, Hukum Pembuktian Cetakan Ke-17, Jakarta: Pradnya Paramita, 2008, hlm. 1.

16 Moch. Faisal Salam, Op.Cit., hlm. 198.
} 
atau tidak. Kalau terdakwa berada dalam tahanan, maka isi putusan berisi dikurangi selama terdakwa dalam tahanan. ${ }^{17}$ Dalam hal terdakwa pernah dijatuhi hukuman disiplin yang berupa penahanan, hukuman disiplin tersebut wajib dipertimbangkan dari pidana yang dijatuhkan. Setelah putusan itu diucapkan di hadapan sidang terbuka untuk umum, maka putusan yang telah diucapkan itu ditanda tangani oleh Hakim dan Panitera, sedangkan petikan dari putusan itu diberikan kepada terdakwa atau penasihat hukumnya dan Oditur segera setelah putusan itu diucapkan. Selain itu salinan putusan diberikan kepada Perwira Penyerah Perkara, Oditurat, POM TNI dan Ankum, sedangkan kepada terdakwa atau penasihat hukumnya diberikan atas permintaan.

\section{KESIMPULAN}

Berdasarkan hasil penelitian yang disesuaikan dengan rumusan masalah menyangkut pertanggungjawaban pidana terhadap pelaku tindak pidana insubordinasi menurut KUHPM dan pembuktian tindak pidana insubordinasi dalam peradilan Militer maka kesimpulan penelitian ini ialah:

1. Pertanggungjawaban pelaku tindak pidana Insubordinasi dengan tindakan nyata terhadap atasan yang dilakukan oleh prajurit atau anggota TNI yang berpangkat lebih rendah sesuai Pasal 106-108 KUHPM harus dipertanggungjawabkan secara hukum pidana Militer yang diatur dalam Kitab Undang-Undang Hukum Pidana Militer (KUHPM) sesuai Pasal 106 bahwa Militer yang sengaja menyerang seorang atasan, melawannya dengan kekerasan atau ancaman kekerasan, merampas kemerdekaannya untuk bertindak ataupun memaksanya dengan kekerasan atau ancaman kekerasan untuk melaksanakan atau mengabaikan suatu pekerjaan dinas, diancam karena insubordinasi dengan tindakan nyata dengan pidana penjara maksimum sembilan tahun, Hukuman tersebut berupa Hukuman Penjara, Pemecatan dari Dinas Militer dan Penurunan Pangkat.

2. Pembuktian pelaku tindak pidana Insubordinasi dengan tindakan nyata melalui pengadilan Militer yang telah dilimpahkan oleh Perwira Penyerah Perkara (PAPERA) melalui Oditur Militer yang disertai dengan surat Dakwaan, Hakim ketua sidang harus membuktikan kesalahan terdakwa apakah terbukti

17 Ibid., hlm. 236. 
atau tidak sebagaimana didakwakan oleh Oditur Militer sesuai Pasal 171 KUHAPMIL yaitu Hakim tidak boleh menjatuhkan pidana kepada seseorang kecuali apabila dengan sekurang-kurangnya dua alat bukti yang sah, ia memperoleh keyakinan bahwa suatu tindak pidana benar-benar terjadi dan bahwa terdakwalah yang bersalah melakukannya.

\section{Daftar Pustaka}

\section{Buku}

Gunadi, Ismu dan Jonaedi Efendi, Cepat dan Mudah Memahami Hukum Pidana, Jakarta: PT Prestasi Pustakaraya, 2011.

Hamzah, Andi, Asas-Asas Hukum Pidana, Jakarta: Rieka Cipta, 1997. Kamus Hukum, Jakarta: Ghalia Indonesia, 1986.

Houck, Max M., Essentials Of Forensic Science: Trace Evidence, New York: An Imprint Of Infobase Publisbing, 2009.

Moeljanto, Asas-Asas Hukum Pidana, Jakarta: Rineka Cipta, 2009.

Mulyadi, Lilik, Pembalikan Beban Pembuktian Tindak Pidana Korupsi, Bandung: Alumni, 2007.

Salam, Moch. Faisal, Hukum Pidana Militer di Indonesia, Bandung: Mandar Maju, 2002.

Saleh, Ruslan, Perbuatan Pidana dan Pertanggungjawaban Pidana, Jakarta: Aksara Baru, 1990.

Schut, P.J.H.O. dan R.W Zandvoort, Engels Woordenboek-Eerste Deel-Engels-Nederlands Groningen-Batavia: J.B. Wolters Uitgeversmaatschappij, 1948.

Soedirjo, Jaksa dan Hakim dalam Proses Pidana, Jakarta: Akademika Pressindo, 1985.

Subekti, R., Hukum Pembuktian Cetakan Ke-17, Jakarta: Pradnya Paramita, 2008.

\section{Peraturan Perundang-Undangan}

Undang-Undang Nomor 39 Tahun 1947 Tentang Kitab Undang-Undang Hukum Pidana Militer (KUHPM).

Undang-Undang Nomor 31 Tahun 1997 Tentang Peradilan Militer. 